solve some of the outstanding problems in Antarctic discovery, is estimated to cost no more than $£ 15,000$, of which the British Government is giving $£ 10,000$ and the Royal Geographical Society $£ 1,000$.

\section{Sir Everard im Thurn Memorial Scholarship}

THE council of the Scottish Anthropological Society proposes to create a permanent memorial of the late Sir Everard im Thurn by founding a lectureship in anthropology. Sir Everard im Thurn was the first president of the Edinburgh and Lothians Branch of the Royal Anthropological Institute, an office which he held from 1924 until 1932, and was one of the first to advocate the formation of a Scottish national society for the advancement of anthropological teaching and research. Sir Everard's distinction as an anthropologist has been widely recognised. $\mathrm{He}$ was the author of the standard work on the Indians of Guiana, contributed numerous papers on anthropological subjects to scientific journals, and was president of the Royal Anthropological Institute in 1919-21. It is intended that the Sir Everard im Thurn memorial lecture should be delivered annually on the date of the annual general meeting of the Society by an anthropologist of note. For this purpose, it is stated in an appeal issued by the memorial committee, of which Prof. H. J. Rose, president of the Society, is chairman, a capital sum of $£ 500$ will be required to meet the annual expenses. Part of this sum has already been provided, but further subscriptions are invited to make up the amount. In the meantime, arrangements have been made for the delivery of the first lecture on May 22, 1934, when Dr. R. R. Marett will lecture on "Sir Everard im Thurn as Anthropologist and as Man". Contributions to the fund should be addressed to the honorary treasurer of the Society, Mr. J. B. Mackay, 30 St. Alban's Road, Edinburgh.

\section{Work of Geological Surveys}

THE presidential address of Sir Thomas Holland at the annual general meeting of the Geological Society on February 16 was mainly devoted to an examination of the organisation of the geological surveys of the British Empire and the United States. $\mathrm{He}$ emphasised the fact that the real object of every such survey is the mineral development of the country, scientific results being obtained as by-products and used as a means to attaining the economic object in view. The work of preparing a geological map requires the co-operation of various specialists of at least seven kinds. With a director and his assistant, a curator and a chemist, the minimum number of scientific officers required for a survey like that of India, for example, is found to be about 21. Below this standard an organisation is scientifically inefficient and economically wasteful. The colonies separately might not be able, for financial reasons, to maintain this standard, but the difficulty could be partially met, as in the Federated Malay States, by a federation of officers in geographically related groups. Important functions of a survey are the classification of public lands and the compilation and analysis of mineral statistics. The director should be well acquainted with the trend of mineral development, watching imports for indications that the country might itself produce certain minerals and by-products. He should therefore be the adviser of his Government on questions of mineral policy, whether in purely economic matters or in the development and conservation of minerals that are essential for the production of munitions of war.

\section{Science and Society}

THE third Hobhouse memorial lecture, on the subject, "Rational and Irrational Elements in our Society", was delivered at Bedford College for Women on March 7 by Prof. Karl Mannheim, formerly professor of sociology in the University of Frankforton-Main, and now lecturer in sociology at the London School of Economies and Political Science. The main theme of the lecture was the problem created for contemporary society through the disproportion between the range of man's technical knowledge, and his moral qualities and rational insight into the social mechanism which it is the task of members of society to control. Society must break down unless this grave disproportion be remedied. Owing to the correlation of the growth of certain moral and spiritual elements with certain features in society, the problem is amenable to scientific treatment. The question to be answered is what are the elements in an industrialised society which tend to heighten rationality and at the same time to promote irrationality. Two senses of rationality must be distinguished. Substantial rationality relates to thinking and understanding, to the cogitative elements in general; functional rationality relates to the organisation of activities for the attaining of given ends calculated from the point of view of a given observer. Modern industrialised society has revealed the power to plan and control possessed by those who are emotion. ally primitive. Our society is faced with the problem of planning the man who has to plan men. Its future depends upon the group within society which has the ability to control, and the energy to subdue the irrational elements.

\section{Birmingham Museum}

The City of Birmingham Museum and Art Gallery, which celebrates its jubilee this year with a series of special exhibitions, the first of which was opened on February 24, may be said to have had its origin in the presentation of Edward Coleman's painting, "Dead Game", by a body of subscribers in 1864, an Art Gallery formed in a room of the Free Library being opened to the public in August three years later. In $1870, £ 1,000$ was raised towards the formation of a Museum of Industrial and Decorative Art, but the establishment of a natural history museum was not mooted until 1887. The project received little support as Dr. Sans Cox had already established a collection at Queen's College, which was later handed over to the corporation. In 1904, however, the City Council decided to allocate the upper floor of the new Art Gallery building, facing Congreve Street, for a natural history museum. 